\title{
A Comparative Efficacy Study of the Panchtikta Ghrita Matra Vasti and Panchtikta Ghrita Marsha Nasya in Cervical Spondylosis
}

Research Article

\section{Punam Sawarkar', Manish Deshmukh², Gaurav Sawarkar ${ }^{3 *}$, Nandini Bhojraj ${ }^{4}$}

1. Associate Professor, Department of Panchakarma, 3. Associate Professor, Department of Rachana Sharir, Mahatma Gandhi Ayurved College, Hospital and Research Centre, DMIMS (DU), Salod (H), Wardha 2. Associate Professor, Datta Meghe College of Pharmacy, DMIMS(DU), Salod (H), Wardha 4. Consultant, Kamdhenu, Panchgavya Govidnyana Anusandhana Kendra, Deolapar, Nagpur, Maharashtra

\begin{abstract}
Introduction- Cervical Spondylosis is now becoming a significant threat to the working population due to its progressive nature of the disease. Modern science provides various types of medical and surgical therapies for Cervical Spondylosis but it is realized that more research is needed for the treatment of Cervical Spondylosis satisfactorily.Aim - To study the efficacy of Panchtikta Ghrita Matra Vasti and Panchtikta Ghrita Marsha Nasya in Cervical Spondylosis. Material \& Method- Open randomized parallel comparative clinical study, Phase 2 trial. 30 patients were randomly equal number $(\mathrm{n}=15)$ recruited in the study in two groups. In Group A, patients were treated with Panchtiktaghrita Matravastiand in Group B with Panchtiktaghrita Marsha Nasya. Subjective criteria for the study was Manya Shool and Manya Stambha whether objective criteria were CBC, ESR and Neck disability index (NDI). Observation \& Result- With respect to the blood investigation CBC and ESR was not found significant $(\mathrm{P}<0.05)$. Moreover, radiological changes in X-ray also not found significantly notable. NDI score was found better in both the groups, but mean score of NDI was suggestively improved in Group B (before 45.03, after 13.06) compare to Group A (before 46.26, after 23.06). Conclusion- Both the treatment modalities i.e. Basti and Nasya was effective in Cervical Spondylosis. Panchtikta Ghrita Marsha Nasya was given good results clinically in the patients compare to Panchtikta Ghrita Matra Vasti, but significant conclusion was not calculated with small sample data. So, large population research study is recommended for further research.
\end{abstract}

Key Words: Panchatikta ghrit, Matra basti, Nasya, Cervical spondylosis.

\section{Introduction}

Cervical Spondylosis is now becoming a significant threat to the working population due to its progressive nature of the disease. Modern science provides various types of medical and surgical therapies for Cervical Spondylosis but it is realized that more research is needed for the treatment of Cervical Spondylosis satisfactorily.

A healthy life has been cherished wish of man since ages, but now a day due to fast developing technological era, sedentary lifestyle and lack of time, people cannot concentrate on their proper regimens and facing so many hurdles. One such hurdle is Cervical Spondylosis (1). Occupational stress, poor posture in sitting or sleeping, day sleep, excessive travelling etc. lead to spondylitic changes in cervical spines.

Treatment is usually conservative in nature; Surgery is occasionally performed and taking long term

* Corresponding Author:

\section{Gaurav Sawarkar}

Associate Professor, Dept. of Rachana Sharir Mahatma Gandhi Ayuved College, Hospital \&

Research Centre, DMIMS(DU), Salod (H), Wardha

Maharashtra, India, 442001

Email Id: drsawarkar.gaurav@gmail.com treatment of modern medicine the chronic use of analgesic affects body badly (2).

Many of the treatment modalities for cervical spondylosis have not been subjected to rigorous, controlled trials. Surgery is advocated for cervical radiculopathy in patients who have intractable pain, progressive symptoms, or weakness that fails to improve with conservative therapy. Surgical indications for cervical spondylotic myelopathy remain somewhat controversial, but most clinicians recommend operative therapy over conservative therapy for moderate-tosevere myelopathy.

According to Ayurveda, Manyasthambha is correlated with Cervical spondylosis which is Vatakapha predominant disorder as it resides in Kasherukagata sandhi and Majja. So, Vatahara and Brumhana Chikitsa are advised in this entity by our Acharyas. Charakacharya described Panchatikta Dravyas and Panchatikta Ksheer and Ghrita Basti in Asthyashrit Vyadhi (3). In Asthivaha Strotodushti Chikitsa Panchatikta Dravya Siddha Ksheer Basti and Sarpi are mentioned and since all these are Rasayana for Asthi Dhatu. He had also mentioned the importance of Sthanic Snehana, Swedana and Basti in Vatdosha Upkramass.(4)

The Nasya Karma is also considered as the best and the most specific procedure for diseases of the head a nd neck-"Urdhwa Jatru-Vikaresu 
Visesannasyamisyate" (5). The rich vascular plexus of nasal cavity provides a direct route into blood stream for medications that easily cross mucus membrane. According to Acharya Charaka, Nose is the gateway of Shira (6). Same is stated by Vagbhatta the nasal passage is considered as the portals of the head "Nasa hi Siraso Dwaram" (7).

According to above concepts all drugs measures introduced through the nose spread throughout the head and its constituent parts and may accordingly influence all the Doshas and diseases situated in these parts (8). Manya shoola lakshana is explained as Greevayah Paschatbhaga Shoola (9). Sushruta had used the words Manyagraha and Manyastambha synonymously and described Manyastambha in Urdhvajatrugata Vata nanatmaja vikara (10) as Manyaha kriyahani. He described the involvement of Kaphavruta Vata in the pathogenesis of Manyasthambha(11). Manyastambha is told as Vata kaphaja even though it is included in Vataja nanatmaja Vyadhi according to Sharangadhara (12).

Bhavaprakasha, Yogaratnakara, Sushruta Samhita, Bhaishajya Ratnavali all advised the use of Nasya for its management. Panchatikta Dravyas i.e. Guduchi (Tinospora cordifolia (Thunb.) Miers), Nimb ( A zadirachta indica A. Juss), Vasa (Adhathoda vasica Nees.), Kanatakari (Solanum Xanthocarpum Schard. Wend1), Patol (Trichosanthes dioica ROXB) involved in Panchtikta Ghrita preparation are Rasayana for Asthidhatu. Charakacharya described Panchatikta Dravyas in Asthivaha Strotodushti Chikitsa in the form of Ksheerbasti and Sarpi (13).

\section{Rationale}

In this period of modernization and fast life, people undergo many unwanted practices like improper sitting posture for long time in offices, continuous work in one posture and over exertion, load bearing movements during travelling and sports - all these factors create undue pressure and compressive injury to the spine and play an important role in producing disease like cervical spondylosis. Cervical spondylosis is a degenerative condition of the cervical spine where it may lead to Cervical spondylotic myelopathy (14).

Main symptoms are Pain \& Stiffness in neck, radiating pain into arms, headache, vertigo, tingling sensation, numbness etc. It disturbs daily routine \& overall life of patient.

This disease is now becoming a significant threat to the working population due to its progressive nature. Modern medical science provides various types of medical and surgical therapies but is seen that none of therapy is satisfactory in cervical Spondylosis. All treatment modules just provide symptomatic relief for short period of time. Hence Ayurveda now coming into focus for chronic types of conditions.

Here in initial stages of the disease Kapha Dosha involvement is present. The Kapha vitiation causes obstruction of Vata. Main factors involving in its pathogenesis are Vata (Vyanavata) and Kapha (Shleshaka Kapha). Dushyas occurring in it are Asthi, majja, snayu, mamsa. Hence, the drugs having Vata Kaphahara properties should be administered. They should have property to prevent the degeneration of bones and promote the regeneration. According to Charakacharya, Basti is prime treatment for Vata diseases (15). By taking into consideration all above facts, in this study use of Panchtikta ghrita(16) was used for Vasti and Nasya in patients having cervical spondylosis.

\section{Specific objectives}

- To study the effect of Panchtikta Ghrita Matra Vasti in Cervical spondylosis

- To study the effect of Panchtikta Ghrita Marsha Nasya in Cervical spondylosis

- To compare effects of the Panchtikta Ghrita Matra Vasti and Panchtikta Ghrita Marsha Nasya in Cervical Spondylosis

\section{Methods}

Trial design- Open randomized parallel comparative clinical study (Phase 2/3). 30 patients were randomly $(\mathrm{n}=15$ in each group) recruited in the study in two groups. In group A, patients were treated with Panchtikta Ghrita Matra Vasti and in group B with Panchtikta Ghrita Marsha Nasya. Not a single change was done after trial commencement.

\section{Participants}

Eligibility criteria for participants:

Inclusion criteria - Patients of either sex with presenting classical symptoms of cervical spondylosis (17), X-ray suggesting cervical spondylosis (18) confirmed by qualified radiologist, Patients above 20 years and $<60$ years, Patient who can make neck extension up to 45 degree angle.

Exclusion Criteria - Age group below 20 years and above 60 years, Cervical Spondylosis with myelopathy and radiculopathy (ICD 10 criteria M47.8), Contraindication and previously treated with Vasti therapy (19), Nasya Anarha (20), Matra Sneha Vasti Anarha, Pregnant and lactating mothers, Recent cervical, spinal, or shoulder surgery or implanted instrumentation or previous surgery for cervical spondylotic myelopathy, Stenosis of the spinal canal, Patients suffering from any infectious disease (like tuberculosis), metabolic disease (like diabetes mellitus and hypothyroidism), or chronic diseases (such as rheumatoid arthritis, systematic lupus erythromatous and ankylosing spondylitis)

Settings and locations where the data were collected:

Concerned patients were selected from the Panchakarma OPD and IPD of MGACH \& RC, Salod $(\mathrm{H})$ with preset diagnostic criteria and who were willing to give informed consent.

Panchtikta Ghrita which is trail drug is supplied by Kamdhenu Panchgavya Govidnyana Anusandhana Kendra, Deolapar, Nagpur, Maharashtra where it was prepared as per Snehapaka vidhi mentioned by Sharangdhara in Sh. Sam. Madh. Kh. ch.9. 
Table 1: Intervention of Panchatikta Ghrita in both the groups

\begin{tabular}{|l|l|l|}
\hline & Group A & Group B \\
\hline Intervention & $\begin{array}{l}\text { Panchtikta } \\
\text { Ghrita Matra } \\
\text { Vasti was } \\
\text { administered } \\
\text { after } \\
\text { preparatory } \\
\text { procedure }\end{array}$ & $\begin{array}{l}\text { Nasya } \text { with lukewarm } \\
\text { Panchtikta } \text { Ghrita } \\
\text { (Mrudu paka) } \text { with the } \\
\text { dose of 8 Bindu } \\
\text { (approximate 4 ml) in } \\
\text { each nostril one by one } \\
\text { with the help of dropper } \\
\text { at 8:30 am for 7 } \\
\text { consecutive days (21) }\end{array}$ \\
\hline $\begin{array}{l}\text { Root of } \\
\text { administration }\end{array}$ & $\begin{array}{l}\text { Anal } \\
\text { Nasal }\end{array}$ \\
\hline $\begin{array}{l}\text { Dosage } \\
\text { day for } \\
\text { consecutive }\end{array}$ & $\begin{array}{l}\text { 8 drops (4 ml) in each } \\
\text { nostril per day for } \\
\text { consecutive 7 days }\end{array}$ \\
\hline $\begin{array}{l}\text { Duration of } \\
\text { intervention }\end{array}$ & 7 days & 7 days \\
\hline $\begin{array}{l}\text { Follow up } \\
\text { Period: }\end{array}$ & 21 days & 21 days \\
\hline $\begin{array}{l}\text { Total Study } \\
\text { duration }\end{array}$ & 28 days & 28 days \\
\hline
\end{tabular}

\section{Outcomes}

Primary outcome of this trial was to compare efficacy of Panchtikta Ghrit Marsha Nasya and Panchtikta Ghrit Matra Basti in Manya Stambha (Spondylosis) in terms of relief in symptoms of Cervical Spondylosis and Improvement(reduction) in Neck Disability Index (NDI) score \& Secondary outcome was to find out radiological changes in cervical spondylosis in both groups. Assessment of the patients was done before intervention, just after completion of interventions (on $8^{\text {th }}$ day) and on the follow up day i.e. $21^{\text {th }}$ day as follows.

\subsection{Subjective Parameters:}

1) Manya shoola (Pain in cervical region):

$0=$ No Pain

$1=$ Pain in neck only after neck movements

$2=$ Continuous pain in neck which further worsen after neck movements

$3=$ Continuous Pain in neck and it radiates towards either upper limb and disturbed the sleep

2) Manya sthambha (Stiffness in Cervical region):

$0=$ No Stiffness,

$1=$ Stiffness up to 1 hour

$2=$ Stiffness up to $2-3$ hours

$3=$ Stiffness up to more than 4-6 hours

\section{Objective Parameters:}

Neck disability Index:

It is a questionnaire used to find out the level of disability of neck before and after treatment. It consists 10 questions such as pain intensity, personal care (like washing dressing), lifting, reading, headache, concentration, work, driving, sleeping, recreation, etc., each having 6 questions ( $0-5$ points). This index was assessed before the day of intervention, just after completion of interventions (on $8^{\text {th }}$ day) and on the follow up day i.e. $21^{\text {st }}$ day as follows.

\section{X-ray cervical spines (Anteroposterior and lateral view):}

Degenerative changes of Cervical spondylosis with mark reduction in cervical spines was assessed through X-ray Cervical regions (AP \& Lateral view) before intervention and on the follow up visit i.e. on $21^{\text {st }}$ day.

Sample size: Total 30 patient were recruited in the study, 15 patients per group.

Randomization/ Sequence generation: Randomization was done by simple lottery method

Implementation- Maintenance of sequence of random allocation, enrollment of patients and assignment of intervention to patients was done by principal investigator.

\section{Statistical methods}

Statistical methods used to compare groups for primary and secondary outcomes. The data obtained in clinical study was subjected to statistical tests paired, unpaired t-test (software sigma stat version 0.2) and analyzed in two parts as; the subjective criteria were assessed before treatment (V1), after treatment(V2), after 14 days (at follow up -V3) by the Wilcoxon signed Rank test. Neck disability index was also assessed on same visits with Paired \& unpaired t-test (for comparison before \&after treatment in same group $\&$ to compare between group respectively) using Graph pad prism software version 7.0 version. $\mathrm{P}$ value $<0.05$ was considered significant. Radiological findings of $\mathrm{X}$ ray were assessed before starting treatment and on $28^{\text {th }}$ day of study.

All patients were instructed to take analgesic according to their choice if pain was aggravated during trial \& If there was further or any complication such as tingling or vertigo arises then such patient will be allowed to undergo physiotherapy. But there were no such incidences occur for any patient.

\section{Results}

30 patients recruited in this clinical trial (15 in each group), all patients received intended treatment for allotted duration and were analyzed for the primary \& secondary outcomes. No patient was drop out from the study and no any adverse event was noted. From the collected data from all 30 patients registered in this trial reflected that there was maximum patients 20 $(66.66 \%)$ were from age group 40-50, 18 patients $(60 \%)$ were females \& from urban population, 25 $(83.33 \%)$ were had sedentary job,20 patients $(67 \%)$ were Hindus, 11 patients $(37 \%)$ were patients suffered from disturbed sleep, 16 patients $(55 \%)$ had disturbed bowel habit \& 21 patients (78\%) were of vatapradhan pittanubandhi prakruti. 
Punam Sawarkar et.al., Panchtikta Ghrita Matra Vasti and Panchtikta Ghrita Marsha Nasya in Cervical Spondylosis

Assessment of the total effect of the therapy

Table 2: Showing Statistical analysis of effect of both interventions on Manyashoola (Pain in cervical region)

\begin{tabular}{|c|c|c|c|}
\hline $\begin{array}{c}\text { Manya } \\
\text { shoola }\end{array}$ & Before $t / t$ & After $\mathrm{t} / \mathrm{t}$ & $\begin{array}{c}\text { Follow Up } \\
\text { Period }\end{array}$ \\
\hline \multicolumn{4}{|c|}{ Group A } \\
\hline Grade 0 & $0(0 \%)$ & $13(70 \%)$ & $10(66.66 \%)$ \\
\hline Grade 1 & $0(0 \%)$ & $2(30 \%)$ & $5(33.33 \%)$ \\
\hline Grade 2 & $3(20 \%)$ & $0(0 \%)$ & $0(0 \%)$ \\
\hline Grade 3 & $8(53.3 \%)$ & $0(0 \%)$ & $0(0 \%)$ \\
\hline Grade 4 & $4(26.7 \%)$ & $0(0 \%)$ & $0(0 \%)$ \\
\hline Fisher Exact & - & 3.600 & 3.733 \\
\hline p-value & - & $<0.001, \mathrm{~S}$ & $<0.001, \mathrm{~S}$ \\
\hline \multicolumn{4}{|c|}{ Group B } \\
\hline Grade 0 & $0(0 \%)$ & $11(80 \%)$ & $15(100 \%)$ \\
\hline Grade 1 & $0(0 \%)$ & $4(20 \%)$ & $0(0 \%)$ \\
\hline Grade 2 & $6(40 \%)$ & $0(0 \%)$ & $0(0 \%)$ \\
\hline Grade 3 & $6(40 \%)$ & $0(0 \%)$ & $0(0 \%)$ \\
\hline Grade 4 & $3(20 \%)$ & $0(0 \%)$ & $0(0 \%)$ \\
\hline$\chi^{2}$-value & - & 2.933 & 3.333 \\
\hline p-value & - & $<0.001, \mathrm{~S}$ & $<0.001, \mathrm{~S}$ \\
\hline \multicolumn{4}{|c|}{ Comparison between Group A and Group B } \\
\hline Fisher Exact & 2.39 & 2.400 & 2.333 \\
\hline p-value & $0.30, \mathrm{NS}$ & $0.011, \mathrm{~S}$ & $0.026, \mathrm{~S}$ \\
\hline
\end{tabular}

*S- Significant, NS- Not Significant

Inference:

From above table and graph, it reflects that in Group A, there were 3,8 and 4 patients had Manyashoola having Grade 2, 3 and 4 respectively. While in Group B, there were 6, 6 and 3 patients with Manyashoola having Grade 2, 3 and 4 respectively. From the observation, it is clear that in Group A, the maximum number of patients with Manyashoola having Grade 3. However, in Group B, there were maximum patients with Manyashoola having Grade 2 and 3. In group A,70\% patients got relief just after intervention $\& 80 \%$ persons got relief after intervention in group B.

The non significant Chi-square value (2.39) and $\mathrm{P}$ value $(\mathrm{P}=0.30)$ while comparison between Group $\mathrm{A}$ and Group B before treatment, it shows that there was uniform distribution.

On comparing just after intervention between Group A and Group B, significant Fisher Exact value (2.40) and $\mathrm{P}$ value $(\mathrm{P}=0.011)$ shows that there is significance between two groups, that means Marsh Nasya with Panchtikta Ghrita is more effective than Matra Vasti with Panchtikta Ghrita to reduce the symptom of Manya shoola.

In Follow up visit, though there was significant relief in Shirashoola after intervention in each group, but after comparison between two groups, the significant Fisher Exact value (2.33) and $\mathrm{P}$ value $(\mathrm{P}=$ 0.026) shows that comparative more effect of Marsh Nasya with Panchtikta Ghrita than the effect of Matra Vasti with Panchtikta Ghrita even after 21 days also.
Table 3: Showing Statistical analysis of effect of both interventions on Manyasthambha (Stiffness in Cervical region)

\begin{tabular}{|c|c|c|c|}
\hline $\begin{array}{c}\text { Manya } \\
\text { Sthambha }\end{array}$ & Before $\mathrm{t} / \mathrm{t}$ & After $t / t$ & $\begin{array}{l}\text { Follow Up } \\
\text { Period }\end{array}$ \\
\hline \multicolumn{4}{|c|}{ Group A } \\
\hline Grade 0 & $0(0 \%)$ & $12(80 \%)$ & $15(100 \%)$ \\
\hline Grade 1 & $0(0 \%)$ & $3(20 \%)$ & $0(0 \%)$ \\
\hline Grade 2 & $2(13.3 \%)$ & $0(0 \%)$ & $0(0 \%)$ \\
\hline Grade 3 & $8(53.3 \%)$ & $0(0 \%)$ & $0(0 \%)$ \\
\hline Grade 4 & $5(33.3 \%)$ & $0(0 \%)$ & $0(0 \%)$ \\
\hline Fisher Exact & - & 3.333 & 3.600 \\
\hline p-value & - & $<0.001, \mathrm{~S}$ & $<0.001, \mathrm{~S}$ \\
\hline \multicolumn{4}{|c|}{ Group B } \\
\hline Grade 0 & $1(6.7 \%)$ & $14(90 \%)$ & $15(100 \%)$ \\
\hline Grade 1 & $0(0 \%)$ & $1(10 \%)$ & $0(0 \%)$ \\
\hline Grade 2 & $5(33.3 \%)$ & $0(0 \%)$ & $0(0 \%)$ \\
\hline Grade 3 & $7(46.7 \%)$ & $0(0 \%)$ & $0(0 \%)$ \\
\hline Grade 4 & $2(13.3 \%)$ & $0(0 \%)$ & $0(0 \%)$ \\
\hline Fisher Exact & - & 3.733 & 3.933 \\
\hline $\mathrm{p}$-value & - & $<0.001$ & $<0.001$ \\
\hline \multicolumn{4}{|c|}{ Comparison between Group A and Group B } \\
\hline Fisher Exact & 3.63 & 2.50 & 2.40 \\
\hline p-value & $0.30, \mathrm{NS}$ & $0.021, \mathrm{~S}$ & $0.103, \mathrm{NS}$ \\
\hline
\end{tabular}

Inference:

From above table and graph, it reflects that in Group A, there were 2, 8 and 5 patients had Manyasthambha having Grade 2, 3 and 4 respectively. While in Group B, there were 1, 5, 7 and 4 patients with Manyasthambha having Grade $0,2,3$ and 4 respectively. From the observation, it was clear that in both groups, the maximum number of patients with Manyasthambha having Grade 3.

From the above table, it again reflects that there were 6, 6 and 3 patients with Manyasthambha in Group A having Grade 1,2 and 3 respectively which shows that after Matra Vasti with Panchtikta Ghrita, there were $80 \%$ patients got relief from Manyasthambha. This means after intervention in control group, the intensity of Manyasthambha was reduced significantly. In the follow up visit of same group, the effect was going on and total number of patients got relief from Manyasthambha.

From the above table, it again reflects that there were $1,8,5$ and 1 patient with Manyasthambha in Group B having Grade 0, 1, 2 and 3 respectively. After Marsh Nasya with Panchtikta Ghrita there were $90 \%$ patients got relief from Manyasthambha. This means after intervention in trial group, the severity of Manyasthambha was reduced significantly. In the follow up visit of same group, the effect was going on and there was not a single patient with Manyasthambha and there was no recurrence.

The non-significant Fisher Exact value (3.63) and $P$ value $(P=0.30)$ while comparison between Group $\mathrm{A}$ and Group B before treatment shows that there was uniform distribution.

On comparing just after intervention between Group A and Group B, the significant Fisher Exact value $(2.50)$ and $P$ value $(P=0.021)$ shows that there was significant difference between two groups, that means Marsh Nasya with Panchtikta Ghrita was more 
effective than group A to reduce the symptom of Manyasthambha.

In Follow up visit, though there was significant relief in Manyasthambha after intervention in each group and after comparison between two groups, the non-significant Fisher Exact value (2.40) and $\mathrm{P}$ value $(\mathrm{P}=0.103)$ shows that group with Marsh Nasya with Panchtikta Ghrita was as effect as that of group A for relief in Manya Sthmbha after 21 days.

Table 4: Calculation of Neck Disability Index (NDI) score before and after the treatment in both groups Group A

\section{Group B}

\begin{tabular}{|c|c|c|c|c|c|}
\hline SN & Before & After & SN & Before & After \\
\hline $\mathbf{1}$ & 23 & 13 & 1 & 23 & 4 \\
\hline $\mathbf{2}$ & 24 & 13 & 2 & 24 & 11 \\
\hline $\mathbf{3}$ & 21 & 12 & 3 & 23 & 11 \\
\hline $\mathbf{4}$ & 24 & 14 & 4 & 22 & 11 \\
\hline $\mathbf{5}$ & 23 & 12 & 5 & 24 & 4 \\
\hline $\mathbf{6}$ & 21 & 11 & 6 & 22 & 10 \\
\hline $\mathbf{7}$ & 23 & 12 & 7 & 23 & 4 \\
\hline $\mathbf{8}$ & 22 & 11 & 8 & 24 & 8 \\
\hline $\mathbf{1 0}$ & 22 & 8 & 9 & 20 & 1 \\
\hline $\mathbf{1 1}$ & 23 & 11 & 10 & 22 & 4 \\
\hline $\mathbf{1 2}$ & 21 & 11 & 11 & 19 & 10 \\
\hline $\mathbf{1 3}$ & 23 & 13 & 12 & 23 & 13.06 \\
\hline $\mathbf{1 5}$ & 22 & 12 & 13 & 22 & 23 \\
\hline
\end{tabular}

Table 5: Statistical analysis of NDI score in both the groups

\begin{tabular}{|c|c|c|c|c|c|c|}
\hline \multicolumn{7}{|c|}{ NDI score before treatment in both Groups } \\
\hline Group & $\mathrm{N}$ & Median & $25 \%$ & $75 \%$ & $\mathrm{~T}$ Value & P Value \\
\hline A & 15 & 22 & 21.25 & 23 & \multirow[b]{2}{*}{212} & \multirow{2}{*}{0.418} \\
\hline B & 15 & 23 & 22 & 23.75 & & \\
\hline \multicolumn{7}{|c|}{ Before \& After the treatment NDI score in Group $A$} \\
\hline Treatment & $\mathrm{N}$ & Median & $25 \%$ & $75 \%$ & T Value & P Value \\
\hline Before TT & 15 & 22 & 21.25 & 23 & \multirow{2}{*}{-120.000} & \multirow{3}{*}{$<0.001, \mathrm{~S}$} \\
\hline After TT & 15 & 12 & 11 & 12.75 & & \\
\hline \multicolumn{6}{|c|}{ Before \& After the treatment NDI score in Group B } & \\
\hline Treatment & $\mathrm{N}$ & Mean & Std Dev & SEM & T Value & P Value \\
\hline Before TT & 15 & 22.533 & 1.457 & 0.376 & \multirow{2}{*}{20.992} & \multirow{2}{*}{$<0.001, \mathrm{~S}$} \\
\hline After TT & 15 & 6.533 & 3.42 & 0.883 & & \\
\hline \multicolumn{7}{|c|}{ NDI score after treatment in both Groups } \\
\hline Group & $\mathrm{N}$ & Median & $25 \%$ & $75 \%$ & $\mathrm{~T}$ Value & $P$ Value \\
\hline A & 15 & 12 & 11 & 12.75 & \multirow{2}{*}{323} & \multirow{2}{*}{$<0.001, \mathrm{~S}$} \\
\hline B & 15 & 4 & 4 & 10 & & \\
\hline
\end{tabular}

*S- Significant, NS- Not Significant

The neck disability index was found significant in both the groups. However, more significant in group B.

There was no restriction of food or regimen while administering Matra Basti; it can be administered continuously in all seasons. Unlike Anuvasana Basti, Matrabasti can be administered to Bala, Vriddha and in Alpagni conditions. There is no Pariharakala for this type of Basti. There were not a single excluded or withdrawn from the study after randomization.

Recruitment: Total duration of intervention was 7 days which was followed by visit after 14 days i.e. on the $21^{\text {st }}$ day.

\section{Outcomes and estimation}

The symptoms were Cervical spondylosis was significantly reduced after interventions in both groups and this relief in symptoms was persisted even on the follow up visit also in both groups. NDI score was found better in both the groups, but mean score of NDI was suggestively improved in Group B (before 45.03, after 13.06) compare to Group A (before 46.26, after 23.06) .But there was no significant changes in radiological findings even just after interventions and on follow up visit $(\mathrm{P}<0.05)$. Though there was significant relief in symptoms of Cervical spondylosis as well as significant reduction in Neck disability index in both groups. However, both these positive findings were significantly more in Group B i.e. Marsh Nasya with Panchtikta Ghrita. 
Punam Sawarkar et.al., Panchtikta Ghrita Matra Vasti and Panchtikta Ghrita Marsha Nasya in Cervical Spondylosis

Table 6: Observations of Hematological parameters in Group A (Matra Vasti treatment)

\begin{tabular}{|c|c|c|c|c|c|c|c|}
\hline Parameter & $\begin{array}{c}\text { Treatment } \\
\text { Name }\end{array}$ & $\mathbf{N}$ & Mean & Std Dev & SEM & T value & $P$ value \\
\hline \multirow{3}{*}{$\mathrm{HB} \%$} & BT & 15 & 12.567 & 1.607 & 0.415 & 0.786 & 0.445 \\
\hline & $\mathrm{AT}$ & 15 & 12.387 & 1.603 & 0.414 & & \\
\hline & Difference & 15 & 0.18 & 0.887 & 0.229 & & \\
\hline \multirow{3}{*}{ TLC } & BT & 15 & 6226.667 & 1084.611 & 280.045 & -0.579 & 0.572 \\
\hline & AT & 15 & 6440 & 1501.808 & 387.765 & & \\
\hline & Difference & 15 & -213.333 & 1427.719 & 368.635 & & \\
\hline \multirow{3}{*}{$\mathrm{N}$} & BT & 15 & 56.8 & 6.603 & 1.705 & -2.219 & 0.043 \\
\hline & AT & 15 & 59.867 & 6.278 & 1.621 & & \\
\hline & Difference & 15 & -3.067 & 5.351 & 1.382 & & \\
\hline \multirow{3}{*}{$\mathrm{L}$} & BT & 15 & 37.6 & 6.045 & 1.561 & 0.935 & 0.366 \\
\hline & AT & 15 & 36.267 & 5.97 & 1.541 & & \\
\hline & Difference & 15 & 1.333 & 5.525 & 1.427 & & \\
\hline \multirow{3}{*}{ Total RBC } & BT & 15 & 4.753 & 0.691 & 0.178 & -0.783 & 0.447 \\
\hline & AT & 15 & 4.803 & 0.672 & 0.174 & & \\
\hline & Difference & 15 & -0.0507 & 0.251 & 0.0647 & & \\
\hline \multirow{3}{*}{ T. Platelet } & BT & 15 & 260733.3 & 96703.87 & 24968.83 & -0.217 & 0.831 \\
\hline & AT & 15 & 262466.7 & 90590.02 & 23390.24 & & \\
\hline & Difference & 15 & -1733.33 & 30918.02 & 7982.998 & & \\
\hline \multirow{3}{*}{ ESR } & $\mathrm{BT}$ & 15 & 29 & 22.656 & 5.85 & 2.098 & 0.055 \\
\hline & $\mathrm{AT}$ & 15 & 24.067 & 19.998 & 5.163 & & \\
\hline & Difference & 15 & 4.933 & 9.106 & 2.351 & & \\
\hline \multirow{3}{*}{$\mathrm{MCH}$} & BT & 15 & 25.9 & 5.487 & 1.417 & 0.301 & 0.768 \\
\hline & AT & 15 & 25.8 & 5.343 & 1.38 & & \\
\hline & Difference & 15 & 0.1 & 1.286 & 0.332 & & \\
\hline
\end{tabular}

Table 7: Observations of Hematological parameters in Group B (Marsh Nasya treatment)

\begin{tabular}{|c|c|c|c|c|c|c|c|}
\hline Parameter & $\begin{array}{c}\text { Treatment } \\
\text { Name }\end{array}$ & $\mathbf{N}$ & Mean & Std Dev & SEM & T value & P value \\
\hline \multirow{3}{*}{$\mathrm{HB} \%$} & BT & 15 & 13.313 & 2.14 & 0.552 & -0.289 & 0.777 \\
\hline & AT & 15 & 13.373 & 1.921 & 0.496 & & \\
\hline & Difference & 15 & -0.06 & 0.805 & 0.208 & & \\
\hline \multirow{3}{*}{ TLC } & BT & 15 & 6800 & 1424.781 & 367.877 & 0.466 & 0.648 \\
\hline & AT & 15 & 6633.333 & 1468.073 & 379.055 & & \\
\hline & Difference & 15 & 166.667 & 1384.437 & 357.46 & & \\
\hline \multirow{3}{*}{$\mathrm{N}$} & BT & 15 & 58.533 & 6.046 & 1.561 & -1.208 & 0.247 \\
\hline & AT & 15 & 61.4 & 8.007 & 2.067 & & \\
\hline & Difference & 15 & -2.867 & 9.187 & 2.372 & & \\
\hline \multirow{3}{*}{$\mathrm{L}$} & BT & 15 & 34.467 & 5.317 & 1.373 & 0.787 & 0.444 \\
\hline & AT & 15 & 32.8 & 7.58 & 1.957 & & \\
\hline & Difference & 15 & 1.667 & 8.2 & 2.117 & & \\
\hline \multirow{3}{*}{ B } & BT & 15 & 3.4 & 2.501 & 0.646 & 0.000 & 1.000 \\
\hline & AT & 15 & 3.4 & 1.882 & 0.486 & & \\
\hline & Difference & 15 & 0 & 2.591 & 0.669 & & \\
\hline \multirow{3}{*}{ E } & BT & 15 & 3.267 & 2.282 & 0.589 & 0.837 & 0.417 \\
\hline & AT & 15 & 2.933 & 1.668 & 0.431 & & \\
\hline & Difference & 15 & 0.333 & 1.543 & 0.398 & & \\
\hline \multirow{3}{*}{ Total RBC } & BT & 15 & 4.611 & 0.676 & 0.175 & -0.235 & 0.817 \\
\hline & AT & 15 & 4.625 & 0.688 & 0.178 & & \\
\hline & Difference & 15 & -0.014 & 0.23 & 0.0595 & & \\
\hline \multirow{3}{*}{ ESR } & BT & 15 & 27 & 20.231 & 5.224 & 0.137 & 0.893 \\
\hline & AT & 15 & 26.533 & 22.627 & 5.842 & & \\
\hline & Difference & 15 & 0.467 & 13.228 & 3.415 & & \\
\hline
\end{tabular}




\begin{tabular}{|l|c|r|r|r|r|r|r|}
\multirow{3}{*}{ MVC } & BT & 15 & 89.047 & 8.641 & 2.231 & -1.237 & 0.236 \\
& AT & 15 & 90 & 7.819 & 2.019 & & \\
\cline { 2 - 9 } & Difference & 15 & -0.953 & 2.984 & 0.77 & & 0.832 \\
\hline \multirow{3}{*}{ MCHC } & BT & 15 & 32.567 & 1.375 & 0.355 & 0.216 & \\
& AT & 15 & 32.459 & 2.074 & 0.536 & & \\
& Difference & 15 & 0.107 & 1.925 & 0.497 & & \\
\end{tabular}

Table 8: Observations of Hematological parameters in Group A (Basti) \& Group B (Nasya) before treatment

\begin{tabular}{|c|c|c|c|c|c|c|c|}
\hline Parameter & $\begin{array}{l}\text { Treatment } \\
\text { Name }\end{array}$ & $\mathbf{N}$ & Mean & Std Dev & SEM & T value & $P$ value \\
\hline $\mathrm{HB} \%$ & $\begin{array}{l}\text { Group A } \\
\text { Group B }\end{array}$ & $\begin{array}{l}15 \\
15\end{array}$ & $\begin{array}{l}12.567 \\
13.313\end{array}$ & $\begin{array}{c}1.607 \\
2.14\end{array}$ & $\begin{array}{l}0.415 \\
0.552\end{array}$ & -1.081 & 0.289 \\
\hline & Group A & 15 & 6226.667 & 1084.611 & 280.045 & \multirow{2}{*}{-1.240} & \multirow{2}{*}{0.225} \\
\hline $1 \mathrm{LC}$ & Group B & 15 & 6800 & 1424.781 & 367.877 & & \\
\hline $\mathrm{N}$ & $\begin{array}{l}\text { Group A } \\
\text { Group B }\end{array}$ & $\begin{array}{l}15 \\
15\end{array}$ & $\begin{array}{c}6226.667 \\
6800\end{array}$ & $\begin{array}{l}1084.611 \\
1424.781\end{array}$ & $\begin{array}{l}280.045 \\
367.877\end{array}$ & -0.750 & 0.460 \\
\hline L & $\begin{array}{l}\text { Group A } \\
\text { Group B }\end{array}$ & $\begin{array}{l}15 \\
15\end{array}$ & $\begin{array}{c}37.6 \\
34.467\end{array}$ & $\begin{array}{l}6.045 \\
5.317\end{array}$ & $\begin{array}{l}1.561 \\
1.373\end{array}$ & 1.507 & 0.143 \\
\hline Total RBC & $\begin{array}{l}\text { Group A } \\
\text { Group B }\end{array}$ & $\begin{array}{l}15 \\
15\end{array}$ & $\begin{array}{l}4.753 \\
4.611\end{array}$ & $\begin{array}{l}0.691 \\
0.676\end{array}$ & $\begin{array}{l}0.178 \\
0.175\end{array}$ & 0.569 & 0.574 \\
\hline $\mathrm{MCH}$ & $\begin{array}{l}\text { Group A } \\
\text { Group B }\end{array}$ & $\begin{array}{l}15 \\
15\end{array}$ & $\begin{array}{c}25.9 \\
29.013\end{array}$ & $\begin{array}{l}5.487 \\
3.396\end{array}$ & $\begin{array}{l}1.417 \\
0.877\end{array}$ & -1.869 & 0.072 \\
\hline $\mathrm{MCHC}$ & $\begin{array}{l}\text { Group A } \\
\text { Group B }\end{array}$ & $\begin{array}{l}15 \\
15\end{array}$ & $\begin{array}{c}32.44 \\
32.567\end{array}$ & $\begin{array}{l}2.224 \\
1.375\end{array}$ & $\begin{array}{l}0.574 \\
0.355\end{array}$ & -0.188 & 0.853 \\
\hline
\end{tabular}

Table 9: Observations of Hematological parameters in Group A (Basti) \& Group B (Nasya) after treatment

\begin{tabular}{|c|c|c|c|c|c|c|c|}
\hline Parameter & $\begin{array}{l}\text { Treatment } \\
\text { Name }\end{array}$ & $\mathbf{N}$ & Mean & Std Dev & SEM & T value & P value \\
\hline \multirow{2}{*}{ HB \% } & Group A & 15 & 12.387 & 1.603 & 0.414 & \multirow{2}{*}{-1.527} & \multirow{2}{*}{0.138} \\
\hline & Group B & 15 & 13.313 & 2.14 & 0.552 & & \\
\hline \multirow{2}{*}{ N } & Group A & 15 & 59.867 & 6.278 & 1.621 & \multirow[t]{2}{*}{-0.584} & \multirow[t]{2}{*}{0.564} \\
\hline & Group B & 15 & 61.4 & 8.007 & 2.067 & & \\
\hline \multirow{2}{*}{$\mathrm{L}$} & Group A & 15 & 36.267 & 5.97 & 1.541 & \multirow[t]{2}{*}{1.392} & \multirow[t]{2}{*}{0.175} \\
\hline & Group B & 15 & 32.8 & 7.58 & 1.957 & & \\
\hline \multirow{2}{*}{ Total RBC } & Group A & 15 & 4.803 & 0.672 & 0.174 & \multirow{2}{*}{0.719} & \multirow{2}{*}{0.478} \\
\hline & Group B & 15 & 4.625 & 0.688 & 0.178 & & \\
\hline \multirow{2}{*}{ MCV } & Group A & 15 & 77.067 & 11.56 & 2.985 & \multirow{2}{*}{-3.589} & \multirow{2}{*}{0.001} \\
\hline & Group B & 15 & 90 & 7.819 & 2.019 & & \\
\hline \multirow{2}{*}{$\mathrm{MCH}$} & Group A & 15 & 25.8 & 5.343 & 1.38 & \multirow[t]{2}{*}{-2.151} & \multirow[t]{2}{*}{0.040} \\
\hline & Group B & 15 & 29.167 & 2.86 & 0.739 & & \\
\hline \multirow{2}{*}{$\mathrm{MCHC}$} & Group A & 15 & 33.113 & 2.658 & 0.686 & \multirow[t]{2}{*}{0.751} & \multirow[t]{2}{*}{0.459} \\
\hline & Group B & 15 & 32.459 & 2.074 & 0.536 & & \\
\hline \multirow{2}{*}{ ESR } & Group A & 15 & 18 & 9 & 45 & \multirow[t]{2}{*}{226.500} & \multirow[t]{2}{*}{0.820} \\
\hline & Group B & 15 & 25 & 8.25 & 33.75 & & \\
\hline
\end{tabular}

There was not significant difference found in hematological parameters and all the hematological values found normal during both the intervention.

ESR was decreased insignificantly just after interventions in both the groups. But there was no statistically significant difference seen between the groups. $\left({ }^{*} \mathrm{p}<0.05\right)$

Overall effect of therapy with Subjective Criteria:

Table 10: Assessment on the basis of relief in subjective criteria

\begin{tabular}{l|c|c|c|c|} 
& Range & Group A & Group B & Total \\
\hline Controlled & $100 \%$ & $0(0 \%)$ & $0(0 \%)$ & $0(0 \%)$ \\
\hline Marked Relief & $\geq 75 \%$ & $12(80 \%)$ & $13(86.67 \%)$ & $25(83.33 \%)$ \\
\hline Moderate Relief & $\geq 50-74 \%$ & $3(20 \%)$ & $2(13.33 \%)$ & $5(16.67 \%)$ \\
Mild Relief & $\geq 25-49 \%$ & $0(0 \%)$ & $0(0 \%)$ & $0(0 \%)$ \\
\hline No Relief & $<25 \%$ & $0(0 \%)$ & $0(0 \%)$ & $0(0 \%)$
\end{tabular}

From the above table, it reflects that when both groups responses were summarized, the patients got marked relief were $12(80 \%)$ and $13(86.67 \%)$ from Group A and B respectively. There were $3(20 \%)$ and $2(13.33 \%)$ patients who got moderate relief from Group A and B respectively. 


\section{Harms}

No any types of adverse event were noted in both groups during this trial which shows the safety nature of both interventions.

\section{Discussion}

\section{Probable Mode of action of Panchatikta Ghrita}

As cervical spondylosis is Asthi majja pradoshaja Vikara as per description of Acharya Charaka that Basti with Sarpi medicated with Panchtikta dravya is more beneficial in such entities. Matrabasti is one of the types of Snehabasti which does snehana as a first line of treatment in Sandhigata vata told by Acharya Sushruta. As Goghrita is Vatapittahara and when it is medicated with Panchtikta dravya it becomes Tridoshahara. The ingredients of the Panchtikta Ghrita is chiefly having Vedanasthapana / Shoolaprashamana effect (Guduchi, Nimba, Vasa, Kantakari, ksheerasarpi) Shothahara (Nimba, Vasa, Kantakari) Vatahara (Patola, Kantakari, Ksheerasarpi) Balya/Bhrimana (Guduchi, Nimba, Patola, ksheerasarpi) Rasayana effect (Guduchi, Nimba, Vasa, Ksheerasarpi). The Ghrita is nullifies the effect of Rukshata and Laghuta of Tikta rasa retaining the Kharatva, which is absolutely helpful to correct the Asthi Dhatu which then corrects the disease progress (21).

Ghrita is Vata-pittashamaka, Balya, Agnivardhaka, Madhura, Saumya, Sheeta Virya, Shula, Jwarahara, Vrishya and Vayasthapaka also. Thus, it pacifies the Vata, improve the general condition of the body and acts as a rejuvenator of the body. Thus, helps in the Samprapti Vighatana of the Manyasthmbha. As well it is having property like Yogavahi which is helpful in increase bio-availability of other drugs without losing its own property. It also contains vitamin D which plays an important role to utilize calcium and phosphorous in blood and bone building. In addition to above antioxidant properties of Ghrita, it prevents the oxidative damage of various tissues \& thus provides protection from various degenerative conditions (22).

As Panchtikta Ghrita is main medication in both groups nourishes the nerves due to its Snigdha property. As it is a type of ketogenic diet and prevents stiffness of the nerves, muscles in regions of neck, shoulders and arms which ultimately results in significant reduction in Stiffness \&Pain. Consistency in relief even after stoppage of procedures in both groups $\&$ significant reduction in severity of symptoms as well as reduction in neck disability shows that Panchtikta Ghrita is anti-inflammatory in nature, it may reduce or checks over further degenerative changes of the cervical spines due to its Bruhana nature also (23).

\section{Probable mode of action of Matra Vasti}

Matravasti with Panchtikta Ghrita is helpful to induce Anulomana of the vitiated Vata Dosha which is responsible for Pain i.e. Manyashoola. Dalhana says that Pureeshadhara Kala and Asthidhara Kala are one and the same. So, we can assume that if we administer drug to the rectum (Pureeshadhara Kala); the Asthivaha Srotas also get nurtured (24).

\section{Probable mode of action of Nasya}

Nasya therapy is considered as best therapy for the diseases or pathologies lying above the clavicle (25). As nose is gateway of brain as per Acharya Vagbhata and all medications administered to nasal orifice, it gets passed to brain \& reaches to the surrounding areas of head \& neck, after that it affects over various Dosha in those areas and checks over pathologies situated in particular region (26).

In the present study maximum patients were females \& incidence rate of cervical spondylosis is more in female which is supported by Ali M. Alsham et .al.2015 stating that Cervical spondylosis is common $(\sim 30 \%)$ in the $>30$ age groups \& prevalence of it is more in women $(7.8 \%$ and $76.2 \%)$ than in men $(73.9 \%$ and $3.3 \%)(27)$.

Insignificant result in radiological improvement in Cervical X -ray spines was found due to due to minimum duration of intervention and study. As both interventions in two groups in current clinical study was given for only 7 days for sample size. As minimum 21 days are required to reach medicine through Rasa dhatu to Asthi dhatu which is assessed through X-ray cervical spines (28).

Statistically reduction in ESR in both the groups just after interventions reflects the antiinflammatory action of Panchtikta Ghrita since there is no significant difference between both the groups.

More significant effect found in Group B may be due to additional local massage \& sudation therapies over face, neck \& shoulder which was done as a preprocedural of Marsh Nasya \& which ultimately improve blood circulation in local area, which provides greater nourishment to this part. Both these therapies alleviate the Rukshata \& Sthmabha induced due to Vata \& Kapha Prakopa. Local Swedana therapy with Nirgundi qwatha over cervical region may helpful to relieve pain, which decreases the intensity of Manyashoola due to its Vata-Kapha hara properties (29).

Simultaneously Dhoomapana with Haridra was also given to all patients recruited in group B for 7 days as a part of post-procedure protocol of Nasya therapy. Likewise, it may be helpful to pacify Kapha Dosha in Cervical region.

\section{Generalizability}

From this clinical trial, considering the significant effectiveness of both interventions in patients with Cervical spondylosis, further multicentric study can be planned with large sample size. Duration of both interventions can be increased by 14 to 21 days for perusal the significant changes in Radiological investigation i.e. X Ray cervical spine.

\section{Interpretation}

Both groups have given a highly significant improvement in reducing symptoms of cervical spondylosis \& reduction in Neck disability index. While comparing between two groups, it was also statistically proved that Nasya with Panchtikta Ghrita is more effective than Matra Vasti with Panchtikta Ghrita in 
reducing symptoms of cervical spondylosis \& improvement in NDI scale. Both interventions are proved as safe i.e. without causing any undue effects. Though rectal route of drug administration is more effective than other routes, however, many conditions such as anal fissure or piles, proctitis are certain contraindications for this type of therapy i.e. this principle is exactly applicable for Matra Vasti also. Many times, especially female patients are more reluctant to undergo such type of anal root therapy. In such cases, Nasya therapy will be the alternative option for the patients. In addition to above, Nasya therapy is quite cost effective than that of Matra Vasti as it requires comparative less amount of drug as well as dietic restrictions, only lifestyle modification advised during Nasya therapy is quite easy to follow in comparison with Matra Vasti. Duration of such restrictions are also less as compared to that of Matra Vasti. Because in Matra Basti, restrictions should be double the duration of intervention of therapy.

\section{Conclusion}

With reference to all findings it is concluded that in Group B, intervention with Marsh Nasya with Panchtikta Ghrita is more effective to reduce the severity of symptoms of Cervical spondylosis as well as effective in reducing neck disability index than that of Group A, intervention of Matra Vasti with Panchtikta Ghrita.

Registration: Registration number and name of trial registry-

Ethical clearance number: DMIMS (DU)/IEC/ June-2017-18/6991

Registration in Clinical trial registry of India (CTRI): CTRI/2019/10/021748

Funding: Medicines (Panchtikta Ghrita) for the study was provided by Kamdhenu Panchgavya Govidnyana Anusandhana Kendra, Deolapar, Nagpur, Maharashtra and the study was partly funded by Datta Meghe Institute of Medical Sciences (Deemed to be University), Wardha, Maharashtra

\section{Conflict of Interest}

No conflict of interest

\section{References}

1. Shibu Varghese, Bird's Eye View on the Radiological Diagnosis of Spinal Disorder and their Panchakarma Management: KalarickalVaidyashala, 2012

2. Sawarkar Gaurav, Suple Yogeshwari, Prevention and management of osteoarthritis. Int. J. Res. Ayurveda Pharm. 2013;4(3):454-458.

3. Sreekumar T., Astanga Hradaya Vaghbhata Sutrasthana- II English Translation and Commentary, Updated Third Edition, Thrissur Kerala, Publication Department Harisree Hospital, February 2011, p. 107-108
4. Tripathi Bramhanand: CharakaSamhita Vol. 2, Chaukhamba SurabharatiPrakashan, Varanasi,C.Si. 2/22, p. 198

5. Sreekumar T., Astanga Hradaya Vaghbhata Sutrasthana- II English Translation and Commentary, Updated Third Edition, Thrissur Kerala, Publication Department Harisree Hospital, February 2011, p. 107-108

6. Sharma Govardhan, Astang Samgraha- Sutrasthana Arthaprakashika Vyakhya, 11th Edition, Varanasi, Chaukhambha Sanskrit Sansthan- Varanasi, 1996, p. 157.

7. Kamath S. A, Medicine: API Textbook of Medicine; The Association of Physician of India, Mumbai, 7th Edition 2003.

8. Shukla Vidyadhara Charaka samhita of Agnivesha, treatise refined and annovated by Charaka and redacted by Dridhbala, Volume II, Chapter 28, Verse 43-44, Chaukhambasanskrita pratisthana, varansi,reprint edition,2007, p.695

9. Sharma P.V. Sushruta Samhita Of Sushruta, Volume II,Nidansthahna,,Chapter 1 ,Verse 67, Chaukhambha Viswabharati,Varanasi,Reprint 2005, p.14

10. Mishra Dwarakaprasad, Sharangadhara Samhita by p a n d i t $\mathrm{s} \mathrm{h}$ a r a $\mathrm{g}$ a d h a r a, shastri,Vidyasagara,Pratahamkhanada, chapter 7, Verse 104,107, ChaukhambaSanskrit series office, Varanasi 1st edition,2010, p.164

11. Mishra Dwarakaprasad, Sharangadhara samhitaby pandit sharangadhara, madhyamakhanada, chapter 9, Verse91-92, ChaukhambaSanskrit series office, Varanasi 1 ${ }^{\text {st }}$ edition, 2010, p.333

12. Shukla Vidyadhar, Tripathi Ravidatta, Charaka samhita of Agnivesha, treatise refined and annovated by Charaka and redacted by Dridhbala, Volume I, Sutrasthana Chapter 28, verse 25, IST edition, 2007, Chaukhamba Publishing House, New Delhi, page no. 431

13. Sreekumar T., Astanga Hradaya Vaghbhata Sutrasthana- II English Translation and Commentary, 3rd edition, Thrissur - Kerala, Publication Department Harisree Hospital, February 2011, p. 110-11

14. Sharma Anant Ram edited Sushrutha Samhita, Vol-1, Nidana Sthana, 1 ${ }^{\text {st }}$ Chapter, Choukamba Surbharati Prakashan, p. 467

15. Shukla Vidyadhar, Tripathi Ravidatta, Charaka samhita of Agnivesha, treatise refined and annovated by Charaka and redacted by Dridhbala, Volume I,Sutrasthana Chapter 28,verse 25, IST edition, 2007,Chaukhamba Publishing House, New Delhi, page no. 431

16. Shastri Kashinath, Chaturvedi Gorakha Nath, Caraka Samhita of Agnivesha Vol. 2, 5th Edition, Varanasi, Chaukhambha Sanskrit SansthanVaranasi, 1977, p. 984-985

17. Marica W. 2nd ed. London: William Meinemann Medical Book Limited; 1971. Cervical spondylosis, its early diagnosis and treatment; pp. 59-67.

18. Marica W. 2nd ed. London: William Meinemann Medical Book Limited; 1971. Cervical 
Punam Sawarkar et.al., Panchtikta Ghrita Matra Vasti and Panchtikta Ghrita Marsha Nasya in Cervical Spondylosis sspondylosis, its early diagnosis and treatment; $p$. 68

19. Kunte Moreshwar and Paradakar Sadashiv, Astanghridyaa, Volume I, Sutrasthana Chapter 19, Verse 8 , Chaukhambasurbharati prakashana, varansi,reprint re-edition,2007,P.N.272

20. Shastri Kashinath, Chaturvedi Gorakha Nath, Charaka Samhita of Agnivesha Vol. 2, 5th Edition, Varanasi, Chaukhambha Sanskrit SansthanVaranasi, 1977, p. 984-985

21. Sawarkar Gaurav, Sawarkar Punam, Avascular Necrosis of Femoral Head Joinsysmed 2016, vol 4(1), $\mathrm{p} 46-50$

22. http://ayushportal.nic.in/panchagavya.html, 13.04.2020, IST 19.35

23. Singh, Sarvesh Kumar, and Kshipra Rajoria. "Ayurvedic approach for management of ankylosing spondylitis: A case report." Journal of Ayurveda and integrative medicine vol. 7,1 (2016): 53-6. doi:10.1016/j.jaim.2015.10.002

24. Dhimdhime Ravindra, Kiran Tawalare, Kalpana Tawalare, Kala Sharir - Testimony Insight from Ayurveda, wjpls, 2016, Vol. 2, Issue 5, 348-353
25. Sreekumar T., Astanga Hradaya Vaghbhata Sutrasthana- II English Translation and Commentary, Updated Third Edition, Thrissur Kerala, Publication Department Harisree Hospital, February 2011, p. 107-108

26. Azeem Ahmad et al. The Effect of Karpasasthyadi Taila Nasya, Physiotherapy in Cervical Spondylosis Available online at: http://ijapr.in Page 24

27. Ali M. Alsham Prevalence of spinal disorders and their relationships with age and gender, Saudi Med J. 2015 Jun; 36(6): 725-730,

28. Mehetre Sunil Tulshiramji, To study the functions of Dhatus according to Ayurvedic kriya Sharir (Dhatukarmabhyas), International Journal of Ayurvedic Medicine, 2015, 6(1) Supplement, 129-133.

29. Mehra Ravina, Samagandhi Kashinath, Study to Evaluate the Preventive Effect of Pratimarsha Nasyaand Dhumapanain Tamaka Shwasaw.s.r. to Seasonal Bronchial Asthma, International Journal of Ayurvedic Medicine, 2017, 8(4), 174-181. 